\title{
Measuring the sustainability of hunting in tropical forests
}

\author{
John G. Robinson and Kent H. Redford
}

Wild animals are an important source of protein for the rural peoples living in or near tropical forests. However, the resource can easily be overexploited and game species can become locally depleted, or even extinct. This paper discusses attempts to measure the sustainability of hunting in tropical forests. It examines five indices of sustainability in current use and two models that attempt to model sustainability.

Being able to determine the sustainability of natural resource use is essential in those situations in which the management goal is both to conserve the resource and to meet the needs and aspirations of the people using that resource. One such situation is hunting by rural peoples in tropical forests. Wild game is an important source of protein for rural people, and its sale is an important source of cash (Redford and Robinson, 1987; Redford, 1993). But wildlife resources in tropical forests are susceptible to overexploitation and game species can be driven to local extinction.

Determining whether hunting in tropical forests is sustainable is difficult because one needs to understand (a) the extent and variation in patterns of hunting, (b) the population status of game species, (c) the productivity of game populations, and (d) the response of game populations to hunting. These data are seldom available for rural communities or for tropical forest game species. Nevertheless, the need to evaluate the sustainability of hunting has resulted in a number of attempts to develop indices and models that provide a first evaluation of sustainability.

In this paper we discuss five indices that have been used to evaluate the sustainability of tropical forest hunting, drawing upon Latin American examples. These indices do not evaluate sustainability directly. Instead, they rely on comparisons of harvest rates or characteristics of game populations to infer sustainability. In addition to these indices we discuss two models that attempt to model sustain- ability. Both depend on some knowledge of the biology of harvested species, and make a number of assumptions derived from studies of temperate species.

\section{Sustainability indices}

Five indices have been used in different studies as measures of sustainability. All measure only one component of sustainability, and thus inference on sustainability is always weak.

\section{Population density comparisons}

The simplest index of sustainability relies on comparisons of wildlife densities in hunted areas with densities in unhunted or control areas. The assumption is that the difference between hunted and unhunted populations reflects the intensity of hunting and allows an inference about sustainability. Such an assumption, however, presupposes that one knows something about how densities vary among sites in the absence of hunting, and also how yield (defined as the harvest that potentially could be taken by hunters) varies with population density. Each of these suppositions is now considered in turn.

A lower density at a hunted site, compared with an unhunted one, does not by itself indicate that hunting is not sustainable. While differences might result from overhunting, they might merely reflect geographical variation in 
densities. For Neotropical mammals, there are enough surveys in the absence of hunting to provide a general appreciation of geographical variation in density for some mammalian taxa (Emmons, 1984), and some understanding of average densities (Robinson and Redford, 1986, 1989). For Neotropical birds, fewer studies have examined densities (but see Thiollay, 1989; Terborgh et al., 1990; Silva and Strahl, 1991) and, while general patterns have not been described, it is probable that the determinants of avian densities will be similar to those described for mammals (J. W. Terborgh, pers. comm.).

A low population density, relative to the supposed carrying capacity $(K)$ of the habitat for the species, also does not, by itself, indicate that hunting is not sustainable. First, because hunting will always lower a population density of the prey. Second, because one also needs to know how yield varies with population density. If the number of births per animal increases as population density decreases, or if mortality drops, then yield is maximized at some density less than $K$. For some temperate species, it is probable that this density, termed the maximum sustainable yield (MSY) point, is achieved at $0.5 \mathrm{~K}$ (for example McCullough, 1979). For tropical forest species, there is little information on the response of game populations to harvesting, but it is probable that yield is maximized much closer to $K$ - densities in the range of $0.65-0.90 \mathrm{~K}$ have been suggested (see Robinson and Redford, 1991). What this means is that if a population density is much below the carrying capacity, yield will be low, and any significant harvest will not be sustainable.

Despite these uncertainties, a number of studies have used relative densities as a general index of sustainability. For example, Bodmer et al. $(1988,1990)$ have argued that the primate harvest in the Tamshiyacu-Tahuayo reserve in northern Peru was not sustainable because densities were much lower than in Manú National Park in southern Peru. However, all that really can be said from this comparison - assuming that the two sites are roughly comparable - is that the potential harvest in Tamshiyacu-Tahuayo is much lower than in Manú, and that the lower densities in the former are the result of hunting. In themselves, density comparisons actually tell us little about the sustainability of the harvest.

\section{Population density declines}

A slightly better index of sustainability relies on density changes at a single site through time. The argument is that a steadily declining wildlife population under hunting indicates that harvest is not sustainable. The decline must be continuous, however, because when hunted the population density of a game species will always decline initially.

Unfortunately long-term data on population densities are seldom available. Most studies examining population densities are of short duration. One exception is Silva and Strahl's (1991) study in which densities of cracids were recorded over a $2^{1 / 2}$-year period. Over this time period, most species showed a decline in density, which the authors ascribed to overhunting.

\section{Hunting yields comparisons}

Hunting yields, or actual harvests, have also been used as an index of sustainability. Hunting yields have been measured in a variety of ways. The simplest measure involves tabulating the total number of animals taken during a specified period, but this does not take into account the number of hunters nor their hunting effort. A better measure is hunting yield per unit effort, where unit effort is measured by the distance, frequency, duration of hunts, or number of hunters (for example Hames and Vickers, 1982; Saffirio and Scaglion, 1982; Stearman, 1990). One inclusive measure that has been proposed is kill rates, which measure the number of kills per manhour of hunting (Vickers, 1991). Note that hunting yields are not the same as game population yields discussed above. Hunting yields are actual harvests, usually measured in terms of unit hunting effort.

Researchers have compared hunting yields among sites and suggested that lower than expected yields indicate that hunting was or is 
unsustainable. The assumption is that game population densities among sites would be similar in the absence of hunting, and that hunting effort at different sites is similar. For example Smith (1976) examined colonist hunting at three locations along the transAmazon highway in Brazil, and concluded that low hunting yields around established settlements were the result of previous overhunting. Beckerman (1978) ascribed the low yield of tapir obtained by the Bari to heavy colonist hunting in the past. However, like comparisons of population densities, comparisons of hunting yields can suggest that game densities are depleted, and that hunting is or was unsustainable, but the argument is indirect and non-conclusive.

\section{Hunting yield changes}

Changes in hunting yield over time indicate more strongly the sustainability of the harvest. Continuous declines generally indicate that hunting is not sustainable and that densities of harvested species are falling. A decline must be maintained, however, because a population recently opened to hunting will always decline until actual harvest balances potential yield, and the increased wariness of animals will accentuate the decline in hunting yields.

The most extensive data on hunting yields in the Neotropics has been provided by Vickers $(1980,1991)$ of a native Siona-Secoya community in north-eastern Ecuador. Vickers tabulated hunting yields in 1973, 1974 and 1975, and again in 1979, 1980 and 1981-82. During the first 3-year period, which immediately followed the establishment of the settlement, hunting yield (measured by weight of meat taken per man-hour of hunting and by kill rates) declined continuously, and Vickers (1980) concluded that game was being depleted. This conclusion may have been premature, because, for most species, hunting yields did not decline further in succeeding years. Accordingly, later Vickers (1991) revised the earlier conclusion and suggested that the harvest of many species was sustainable.

One complication with interpreting hunting yield patterns is that they must take into ac- count changes in the species composition of harvested game. Hunters in the Neotropics tend to prefer large-bodied animals, which have a lot of meat, and 'tasty' animals (frequently frugivorous and granivorous species). When populations of these species are overhunted, then densities decline and hunters shift to less-preferred prey, which generally tend to be smaller (Hames and Vickers, 1982; Stearman, 1990; Vickers, 1991). Small-bodied prey generally occur at higher densities than large-bodied prey (Robinson and Redford, 1986) and, therefore, under these circumstances, overall hunting yield, when measured by kill rates, can actually increase following overhunting of preferred game species. Vickers (1991) for example, reported increases in kill rates of less preferred species, such as agoutis, squirrels, armadillos and caiman over a 10-year period, and decreases in kill rates of more preferred species such as woolly monkey and cracids. Yet hunting yield (measured as kg meat per man-hour of hunting) did not decline over the study period.

Another complication is the need to take into account changes in human communities. For example Ayres and Ayres (1979) examined hunting yields in the small town of Dardanelos, in the Brazilian state of Mato Gross in 1978. Two years later, hunting yields were again surveyed after a road had reached the town and allowed much easier movement of people and goods (Ayres et al., 1991). Game yield (measured by meat weight) had declined to 30 per cent of its earlier total. The diversity of game species declined dramatically and certain groups, such as primates, had disappeared entirely. Yet Ayres and his colleagues did not ascribe these declines to declining populations of wildlife species. Instead they pointed to social changes in the community; the increased commercialization of game with specialized hunters focusing on the most saleable species; the increased access to domestic meat; the influx of newcomers with little knowledge of tropical forest hunting and the outflux of previous residents to gold-producing areas; and the need of many people to work their land to secure title to it.

In summary, whether hunting yields 


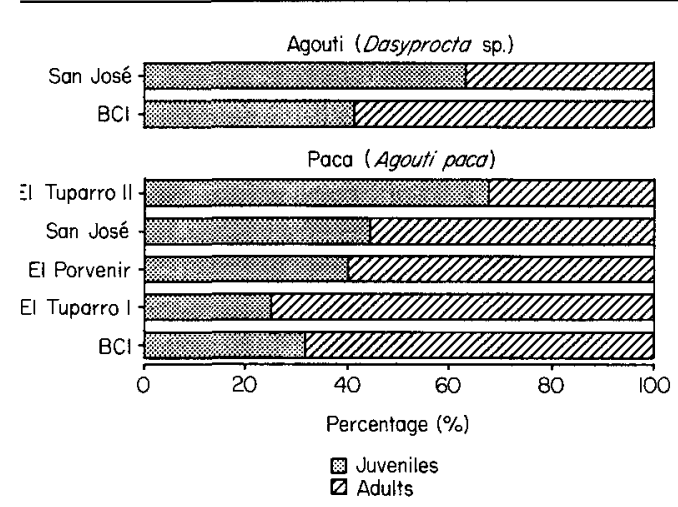

Figure 1. Age structure of rodent populations with hunting intensity. Within each species, study sites are arranged in order of decreasing hunting pressure. The data from San José de Payamino in the Ecuadorian Amazon comes from Irvine (1987). Tuparro $I$ is an unhunted site in the Colombian llanos, El Porvenir is moderately hunted, and Tuparro II is a heavily hunted site (Collett, 1981). The Barro Colorado Island (BCI) data, an unhunted site, comes from Smythe et al. (1982).

decline or not, the interpretation is problematic. Wildlife densities might indeed be declining or stable, the immigration of wild animals into hunting areas might be masking changes in game populations, or hunting yields might merely be a result of changes in game compositions and/or the human community.

\section{Age-structure comparisons}

The distribution of ages within a population responds to harvesting, and thus can provide an index of the sustainability of that harvest. Harvested populations generally are subject to greater mortality in the older (and larger) age classes. This decreased survivorship is reflected in juveniles making up a higher proportion of the population and in a 'flatter' agepyramid.

The proportions of juveniles and adults in two rodent species - agouti Dasyprocta spp. and paca Agouti paca - which are extensively hunted throughout Latin America, are illustrated in Figure 1. The data from San José de Payamino in the Ecuadorian Amazon (Irvine, 1987) and the Colombian llanos (Collett, 1981) come from actual harvests. The Barro

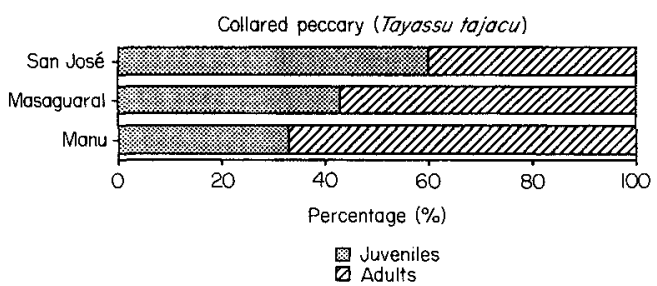

Figure 2. Age structure of peccary populations with hunting intensity. Sites are arranged in order of decreasing hunting pressure. Populations at San José de Payamino are hunted while those at Masaguaral in the Venezuelan llanos (Robinson, unpubl. data) and Manú (Kiltie, 1980) are infrequently hunted.

Colorado Island data come from demographic censuses of wild populations (Smythe et al., 1982). The sites are arranged in order of decreasing intensity of hunting (quantified by the authors using different methodologies), and illustrate how the proportion of adults falls in hunted populations. A similar pattern is evident in Figure 2, which compares age structures in collared peccary Tayassu tajacu populations. The San José de Payamino sample was based on harvests, the other two sites on field censuses and, again, are arranged in order of decreasing hunting intensity. A high proportion of juveniles in a population, therefore, can be used as a measure of hunting intensity, and has been used to comment on sustainability (for example, Irvine, 1987).

More complete age-structure descriptions for Neotropical forest game are seldom available, with a few notable exceptions. Collett (1981) used tooth eruption patterns and annual rings in the cementum of upper molars in Agouti paca to generate 13 age classes, and then relate age-specific survivorship to hunting intensity. Bodmer and his colleagues (Bodmer, in press) have used a similar technique to generate population age structures for ungulates at Taperinha, an eastern Brazilian Amazon site near Santarém, and at Tahuayo-Blanco in the Peruvian Amazon. Both studies were able to relate differences in age-specific survivorship at different sites to putative hunting intensity. 
Variation in the age structure of populations, therefore, can quantify the impact of hunting on wild game populations and allow some statement on relative sustainability, but in the absence of other measures, age-structure differences do not indicate whether or not hunting is sustainable.

\section{Sustainability models}

Two theoretical models have been developed to evaluate the sustainability of hunting in Neotropical forests. Both require information on the demographic characteristics of game populations.

\section{Population analysis model}

Bodmer and colleagues at Tahuayo have developed a simple and elegant model of harvest sustainability, which estimates population production $(P)$. The model requires estimates of (i) reproductive productivity (young produced/female/year) and (ii) population density. Comparison of production with a known harvest in a specified catchment area can then provide a direct measure of sustainability.

Few sites are studied well enough to allow estimates of these parameters for the game species, but Tahuayo in the Peruvian Amazon is an exception. Bodmer and his colleagues (Bodmer, in press) were able to describe the age structure of ungulate populations. The investigators then calculated an index of reproductive activity for females by noting whether animals were carrying fetuses, were lactating or had no reproductive activity. These data allowed them to calculate an index of total reproductive productivity (average number of young/individual/year). Field censuses generated population densities of game species, which multiplied by reproductive productivity allowed an estimate of production measured as individuals $/ \mathrm{sq} \mathrm{km}$. Estimates of total harvest and known catchment areas (hunting areas) then allowed an estimate of hunting pressure (individuals harvested/sq $\mathrm{km}$ ). Comparison of these last two figures allow a direct measure of sustainability.
An example from Tahuayo will illustrate the model. Examination of the reproductive condition of female collared peccaries brought in by hunters revealed that 43.6 per cent were reproductively active, having about 1.5 gestations per year with an average litter size of 1.7. This generated 1.11 young/female/year. Assuming a 1:1 population sex ratio, the average number of young/individual/year will be 0.55 . Surveys revealed an overall density of 3.3 collared peccary/sq $\mathrm{km}$, yielding a total production of 1.83 individuals $/ \mathrm{sq} \mathrm{km}$. The measured harvest was 0.27 individuals $/ \mathrm{sq} \mathrm{km}$. Hunters were, therefore, taking about 15 per cent of total production, which, based on comparable temperate mammal data, is probably sustainable.

The model makes no assumptions about the relationship between game population density and yield and does not seek to estimate MSY. The model does assume that preharvest mortality was not significant and this might be significant in some species. And the model itself does not indicate what proportion of production could be harvested.

\section{Population growth model}

Robinson and Redford (1991) have developed a more general model for Neotropical forest mammals. This population growth model evaluates whether an actual harvest is possibly sustainable under conditions of maximum game production.

From the published literature, Robinson and Redford calculated the population density at carrying capacity $(K)$ for a number of game species, and also the intrinsic rate of population increase $\left(r_{\text {max }}\right)$ of those species, defined as the highest rate of population increase by a population not limited by food, space, resource competition, or predation. The model assumes that (i) $r_{\max }$ is achieved at $0.6 \mathrm{~K}$, (ii) $r_{\max }$ can be achieved in game populations, (iii) that harvested populations can be managed so that they remain at or near $0.6 \mathrm{~K}$. These assumptions are not conservative - the model generates the maximum potential production (individuals/sq $\mathrm{km}$ ) for each species. The model then makes a further assumption: 

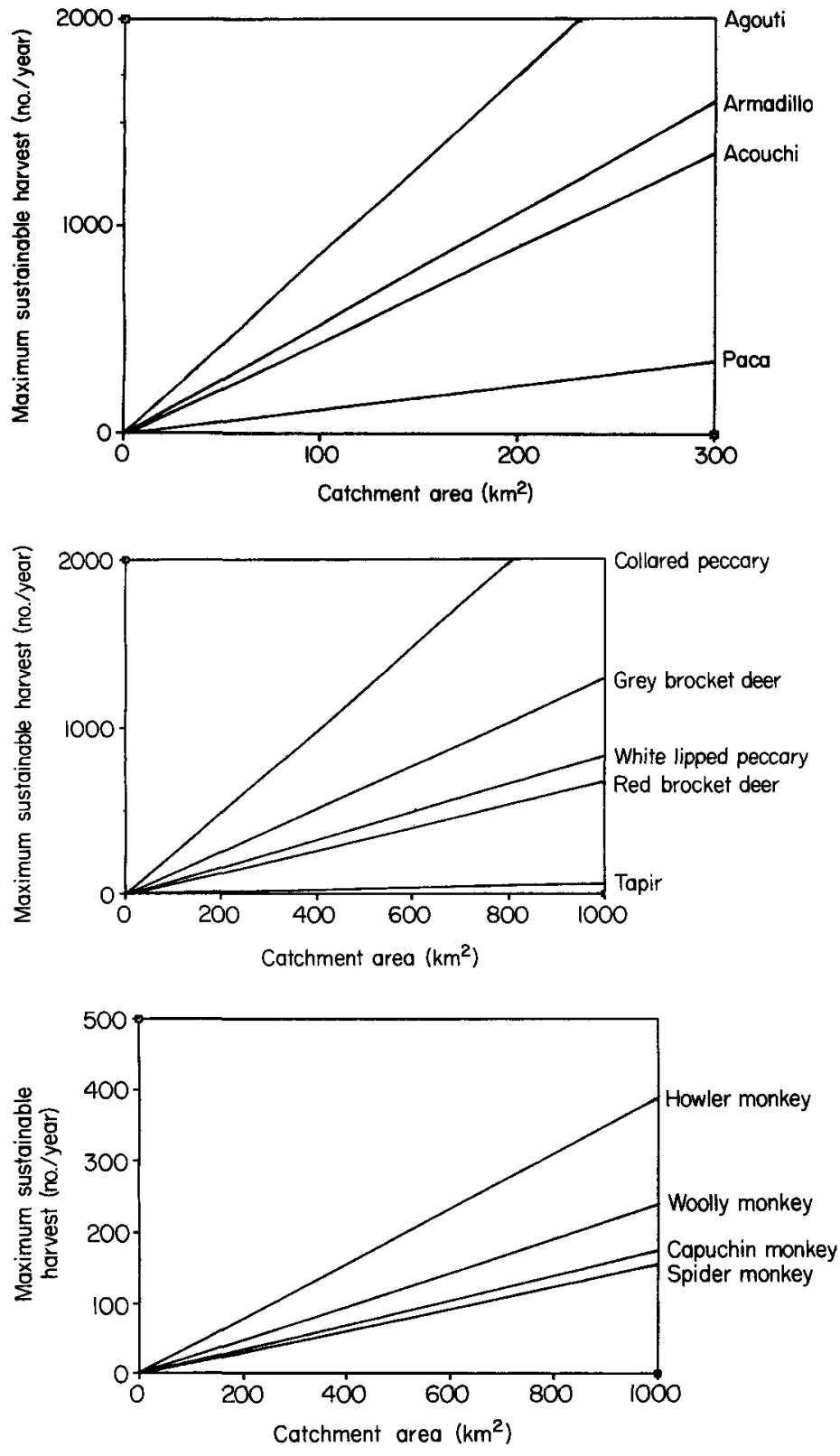

Figure 3. Maximum sustainable harvest of rodents and the ninebanded armadillo with hunting catchment area. For each species a harvest rate above the line cannot be sustainable.
Figure 4. Maximum sustainable harvest of ungulates with hunting catchment area. For each species a harvest rate above the line cannot be sustainable.

Figure 5. Maximum sustainable harvest of primates with hunting catchment area. For each species a harvest rate above the line cannot be sustainable.

(iv) that the proportion of production $(P)$ that can go into yield is 60 per cent for very shortlived species, 40 per cent in short-lived species and 20 per cent in long-lived species. This allows calculation of the maximum potential yield of these species. Real populations would be unlikely to generate yields as high and it is impossible for them to generate higher yields.
An example will illustrate the model. The expected density of spider monkeys in unhunted sites, based on a large number of surveys across the Neotropics, is 16.6 individuals/sq $\mathrm{km}$. The model assumes that hunted populations will have a density of 10.0 individuals $/ \mathrm{sq} \mathrm{km}$ (or $0.6 \mathrm{~K}$ ). Based on reproductive parameters under optimal conditions, 
the expected finite rate of pollution increase is 1.08. The total annual sustainable production of spider monkeys is then 0.8 animals $/ \mathrm{sq} \mathrm{km}$ $[(10.0 \times 1.08)-10.0]$. Of these, only 20 per cent are potentially available for harvest because this species is long-lived, generating a potential sustainable harvest of 0.16 animals/sq $\mathrm{km} /$ year. Any harvest greater than this is almost certainly not sustainable.

The harvest available to a local community varies with the catchment area over which hunters are taking game. To illustrate the maximum sustainable harvests based on this model for a number of important game species, we plotted potential harvests for rodents, ungulates and primates across a range of catchment areas in Figures 3-5.

Actual harvest above each line for each species will not be sustainable. The model allows the evaluation of whether an actual harvest is not sustainable. However, the model does not allow the conclusion that an actual harvest is sustainable. Actual harvests below each line might be sustainable but they might not. Low harvests might be a consequence of depleted game densities, less than maximum birth rates, higher than minimum mortality rates, etc. A further weakness of the model is that it makes a number of assumptions, listed earlier, which may not be justified. In addition, the model assumes specified relationships between population density, yield and natural mortality, which, while reasonable, have not been demonstrated for Neotropical forest mammals.

\section{Conclusion}

Being able to measure the sustainability of hunting is critical where the goals are to both protect the game species and to meet the subsistence needs of the hunters. From this review it is clear that indices and models are available that provide a preliminary measurement of hunting sustainability in tropical forest systems. These allow the determination of whether the population production exceeds or is less than harvest demand at a given moment in time.
This determination, however, by itself does not allow the conclusion that the harvest will continue to be sustainable or not over the long term. Both population density and harvests are dynamic through time because production varies with population density (through density-dependent effects) and because hunting effort (time or energy allocated to hunting) varies with profitability (hunting success per unit effort). For example, when game populations are dense, hunting profitability is high, and harvests frequently exceed production. A common pattern is for harvest to exceed production for a period after hunting of a population is initiated. This drives population densities and hunting yields down. This will in turn affect production and hunting effort. The relationship between game population density and game harvest is therefore a dynamic one, but under a defined set of social and ecological conditions, it will tend to approach a stable state. This will be the point when the production generated by a given population density balances the harvest taken by hunters. At that point, if the population density of the game species is too low (i.e. the long-term viability of the population is threatened), then harvest is not biologically sustainable. And at the same point, if the harvest of the population does not meet the socioeconomic needs of the hunters, then the harvest is not socioeconomically sustainable. Hunting is sustainable in the long term only if the harvest is both biologically and socioeconomically sustainable (Robinson, 1993). One of the challenges for the future is to define the range of population densities and harvest rates where these two conditions are met.

\section{References}

Ayres, J.M. and Ayres, C. 1979. Aspectos da caça no alto rio Aripuanã. Acta Amazonica, 9, 287-298.

Ayres, J.M., Lima, D. de M., Martins, E. de S. and Barreiros, J.L.K. 1991. On the track of the road: changes in subsistence hunting in a Brazilian Amazonian village. In Neotropical Wildlife Use and Conservation (eds J. G. Robinson and K. H. Redford), pp. 82-91. University of Chicago Press, Chicago.

Beckerman, S. 1978. Comment on Ross. Current 
Anthropology, 19, 17-18.

Bodmer, R.E. In press. Managing wildlife with local communities: the case of the Reserva Comunal Tamshiyacu-Tahuayo. In Natural Connections (eds D. Western, M. Wright and S. Strum). Island Press, Washington DC.

Bodmer, R.E., Bendayán, A., N.Y., Moya, I.,L. and Fang, T.G. 1990. Manejo de ungulados en la Amazonia Peruana: Analisis de su caza y commercializacion. Boletin de Lima, 70, 49-56.

Bodmer, R.E., Fang, T.G. and Moya I., L. 1988. Primates and ungulates: a comparison of susceptibility to hunting. Primate Conservation, 9, 79-83.

Collett, S.F. 1981. Population characteristics of Agouti paca (Rodentia) in Colombia. Publications of the Museum, Michigan State University, Biological Series, 5, 489-602.

Emmons, L.H. 1984. Geographic variation in densities and diversities of non-flying mammals in Amazonia. Biotropica, 16, 210-222.

Hames, R. and Vickers, W. 1982. Optimal foraging theory as a model to explain viability in Amazonian hunting. American Ethnologist, 9, 358-378.

Irvine, D. 1987. Resource management of the Runa Indians of the Ecuadorian Amazon. PhD dissertation, Stanford University, USA.

Kiltie, R. 1980. Seed predation and group size in rain forest peccaries. $\mathrm{PhD}$ dissertation, Princeton University, USA.

McCullough, D.R. 1979. The George Reserve Deer Herd: Population Ecology of a K-selected Species. University of Michigan Press, Ann Arbor.

Redford, K.H. 1993. Hunting in Neotropical forests: a subsidy from nature. In Tropical Forests, People and Food (eds C. M. Hladik, A. Hladik, O. F. Linares, H. Pagezy, A. Semple and M. Hadley), pp. 227-246. UNESCO, Paris.

Redford, K.H. and Robinson, J.G. 1987. The game of choice: patterns of Indian and colonist hunting in the neotropics. American Anthropologist, 89, 650-667.

Robinson, J.G. 1993. The limits to caring: sustainable living and the loss of biodiversity. Conservation Biology, 7, 20-28.

Robinson, J.G. and Redford, K.H. 1986. Body size, diet and population density of Neotropical forest mammals. American Naturalist, 128, 665-680.

Robinson, J.G. and Redford, K.H. 1989. Body size, diet and population variation in Neotropical forest mammal species: predictors of local extinction? In Advances in Neotropical Mammalogy (eds J. F. Eisenberg and K. H. Redford), pp. 567-594. Sandhill Crane Press, Gainesville, Florida.

Robinson, J.G. and Redford, K.H. 1991. Sustainable harvest of Neotropical forest animals. In Neotropical Wildlife Use and Conservation (eds J. G.
Robinson and K. H. Redford), pp. 415-429. University of Chicago Press, Chicago.

Saffirio, J. and Scaglion, R. 1982. Hunting efficiency in acculturated and unacculturated Yanomama villages. Journal of Anthropological Research, 38, 315-327.

Silva, J.L. and Strahl, S.D. 1991. Human impact on populations of chachalacas, guans and currasows (Galliformes: Cracidae) in Venezuela. In Neotropical Wildlife Use and Conservation (eds J. G. Robinson and K. H. Redford), pp. 37-52. University of Chicago Press, Chicago.

Smith, N.J.H. 1976. Utilization of game along Brasil's transAmazon highway. Acta Amazonica, 6, 455-466.

Smythe, N., Glanz, W. and Leigh Jr., E.G. 1982. Population regulation in some terrestrial frugivores. In The Ecology of a Tropical Forest (eds E. G. Leigh, Jr, A. S. Rand and D. M. Windsor), pp. 227-238. Smithsonian Institution Press, Washington DC.

Stearman, A.M. 1990. The effect of settler incursion on fish and game resources of the Yuquí, a native Amazonian society of eastern Bolivia. Human Organization, 49, 373-385.

Stearman, A.M. 1992. Neotropical indigenous hunters and their neighbours. In Conservation of Neotropical Forests. Working from Traditional Resource Use (eds K. H. Redford and C. Padoch), pp. 108-128. Columbia University Press, New York.

Terborgh, J.W., Robinson, S.K., Parker, T.A., Munn, C.A. and Pierpont, N. 1990. Structure and organization of an Amazonian forest bird community. Ecological Monographs, 60, 213-238.

Thiollay, J.M. 1989. Area requirements for the conservation of rain forest raptors and game birds in French Guiana. Conservation Biology, 3, 128-137.

Vickers, W.T. 1980. An analysis of Amazonian hunting yields as a function of settlement age. In Working Papers on South American Indians (eds W. T. Vickers and K. M. Kensinger), pp. 7-29. Bennington College, Vermont.

Vickers, W.T. 1988. Game depletion hypothesis of Amazonian adaptation: data from a native community. Science, 239, 1521-1522.

Vickers, W.T. 1991. Hunting yields and game composition over ten years in an Amazonian village. In Neotropical Wildlife Use and Conservation (eds G. Robinson and K. H. Redford), pp. 53-81. University of Chicago Press, Chicago.

John G. Robinson, Wildlife Conservation Society, 185th and Southern Boulevard, Bronx, New York 10460, USA.

Kent H. Redford, The Nature Conservancy, 1815 North Lynn Street, Arlington, Virginia, USA. 